Reiko Tsuyuoka 1 J. Wendy Bailey 1 Alzira M. d'Avila Nery Guimarães 2 Ricardo Q. Gurgel 2 Luis E. Cuevas 1

\title{
Anemia and intestinal parasitic infections in primary school students in Aracaju, Sergipe, Brazil
}

\author{
Anemia e parasitoses intestinais em escolares \\ de primeiro grau em Aracaju, Sergipe, Brasil
}

1 Liverpool School of Tropical Medicine. Pembroke Place, Liverpool L3 5QA, UK.

2 Universi dade Federal de Sergipe, Núcleo de Pós-Graduação em Medicina. Rua Claudio Batista s/no sala 125, 20 andar, Bairro Sanatório, Aracajú, Sergipe, 49060-100, Brazil.
Abstract Anemia is estimated to affect half the school-age children and adolescents in developing countries. The main causes are parasitic infections, malaria, and low iron intake. This study aimed to describethe prevalence of anemia, parasitic infections, and nutritional status of children attending public primary schools in Aracaju, Northeast Brazil. Of 360 students, $26.7 \%$ were anemic, and preval ence was higher in children under 8 and over 15 years of age. Overall prevalence of intestinal parasites was $42 \%$, with Ascaris lumbricoides (28.7\%), Trichuris trichiura (15.6\%), and hookworm (1.7\%) most frequently found. There was an association between parasitic infections and poor sanitary conditions, but there was no association between anemia and presence of intestinal parasites. Height-for-age Z scores were lower than the NCHS standard, and prevalence of stunting was $5.4 \%$. Although intestinal parasites were not associated with anemia, children with parasites had lower nutritional indices (weight- and height-for-age $Z$ scores) than those without parasites.

Key words Anemia; Parasites; Nutritional Status; Anthropometry; School Health

Resumo Estima-se que a anemia afeta metade dos escol ares e adol escentes nos países em de senvolvimento. As principais causas são enteroparasitoses, malária e/ou baixa ingesta de ferro. Este estudo objetivou descrever a prevalência de anemia e de enteroparasi toses, assi m como o estado nutricional de escolares de primei ro grau de escol as públicas munici pais de Aracaju, $\mathrm{SE}$, Brasil. Dos 360 estudantes, 26,7\% estavam anêmicos, sendo a prevalência maior nos menores de oi to anos e nos mai ores de 15. A prevalência geral de enteroparasi toses foi de $42 \%$. Ascaris lumbricoides (28,7\%), Trichuris trichiura (15,6\%) e ancilostomídeos $(1,7 \%)$ estavam entre os mais freqüentemente encontrados. Houve associ ação entre enteroparasi tose e má condição de saneamento, mas não entreanemia e presença de enteroparasitos. Os escores de desvio padrão (Z-scores) de altura para idade foram inferiores aos padrões do NCHS, com prevalência de 5,4\% de desnutrição pregressa (stunting). Apesar de as enteroparasitoses não terem sido associadas com ane mia, as crianças quetinham parasitas ao exame apresentavam pior estado nutricional (peso/altura) que aquel as cujos exames resultaram negativos.

Palavras-chave Anemia; Parasitos; Estado Nutricional; Antropometria; Saúde Escolar 


\section{Introduction}

Anemia is the most common manifestation of disease observed in the tropics. Iron-deficiency anemia affects about 1.3 billion people, with the highest prevalence and morbidity in young children and pregnant women (Gillespie et al., 1991). It is estimated that up to half of schoolage children in developing countries are anemic (DeM aeyer et al., 1989). Anemia in infants and children is associated with increased mortality (Stoltzfus, 1997), growth retardation (Angeles et al., 1993), delayed motor development, poor cognitive abilities (Watkins \& Pollitt, 1998), reduced school performance (Lozoff et al., 1991), and an impaired immune system (Dallman, 1987).

Schoolchildren are an easily identified target group, and schools could be used as a distribution system for public health. However, interventions must be based on epidemiological information concerning the main local causes of anemia. Most Latin America countries lack such information, and the Pan-American Health Organization of the World Health Organization (PAHO/WHO) has proposed collecting the necessary information (Freire, 1997).

This study aimed to establish the prevalence of anemia, intestinal parasites, and nutritional status of children attending primary schools in Aracaju, Brazil.

\section{Materials and methods}

This was a cross-sectional descriptive study involving public primary school students in Aracaju, Sergipe, Northeast Brazil. Aracaju has a tropical climate with temperatures ranging from 20 to $30{ }^{\circ} \mathrm{C}$. Eighty percent of Aracaju's 200 primary schools are public and $20 \%$ private (Fapese, 1996). One public school was randomly selected for each of the 5 urban health districts, and the students were selected by age group ( $<8,9$ to 11,12 to 14 , and $>15$ years). All students attending during a normal working day in the selected schools were enrolled. Data were collected during April and May 1998.

The estimated sample size to establish the prevalence of anemia and intestinal parasites was 81 students per age group, assuming that the prevalence of anemia and intestinal parasites was $30 \%$ with a precision of $\pm 10 \%$. This sample size was increased to 90 per age group to allow for a $10 \%$ dropout.

Interviews were performed by local nursing and medical students under the supervision of the principal investigator (R. T.) to obtain in- formation on sanitary conditions at home, past and present illnesses, and parents' education. Parents' education was grouped into complete or incomplete primary education. Weight was measured using a standing scale and height was obtained using a paper stadiometer attached to a straight wall.

Blood samples were collected by finger prick. Hemogl obin concentration was determined by the HemoCue blood $\mathrm{Hb}$ system (HemoCue Ltd, Scheffield, UK) and Hematocrit was measured using heparinized micro-hematocrit tubes and a micro-hematocrit centrifuge (Ames Ltd, Bedfordshire, UK). Thin blood films were fixed and stained with Leishman's stain for the presence of microcytic and hypochromic anemia and to exclude sickle-cell anemia. Anemia was defined as a hemoglobin of less than $110 \mathrm{~g} /$ I for children under 6 years old, less than $120 \mathrm{~g} / \mathrm{I}$ for male and female children between 6 14 years of age and females over 15 year of age, and less than $130 \mathrm{~g} / \mathrm{I}$ in boys over 15 years of age according to the WHO definition of anemia (DeM aeyer, 1985). Mean corpuscular hemoglobin concentration (MCHC) was calculated from the hemoglobin and hematocrit. Definite iron deficiency anemia was defined as a MCHC below $30 \%$ in the presence of microcytosis and hypochromia. An M CHC between 30 and 32\% in the presence of low hemoglobin was considered a possible case of iron deficiency.

Stool containers were distributed the day before the survey to obtain a fecal sample. Samples were fixed the same day with $10 \%$ for$\mathrm{mol}$ - saline and the volumetric concentration technique was used the following day. All parasite ova and cysts seen on $x 10$ and $\times 40$ microscopy were recorded. The number of hookworm ova were counted and expressed as number of eggs per grams (epg) of feces as described by Ashford et al. (1992). A random sample of $10 \%$ of blood films and stools were reexamined in Liverpool for quality control.

Data were analyzed using Epi-Info Version 6 (Dean et al., 1995) to calculate the prevalence of anemia and parasites. Chi-squared and chi-squared for trend were used to test differences of discrete variables and trends. Comparison of nutritional status of the children to the NCHS reference population was performed using the Epinut program within Epi-Info. Wasting, stunting, and mixed malnutrition were defined as a score below -2Z-scores of weight/ height (WHZ), height/age (HAZ), and weight/age (WAZ), respectively.

Children and parents were provided with reports of the examination with an explanatory note about prevention of anemia and parasite 
infections. School staff were informed of any case of moderate or severe anemia and schistosomiasis. Informed consent was obtained from parents of participating children. This study was approved by the Liverpool School of Tropical Medicine Research Ethics Committee and the Federal University of Sergipe post-graduate research committee.

\section{Results}

Three hundred and sixty students were enrolled. Three hundred and fifty-four blood samples (98.3\%) were collected from the students. The age distribution was 4 to 24 years. One hundred and eight students were under 8 years old, 124 were 9 to 11 years old, 85 were 12 to 14 years old, and 43 over 15 years old. One hundred and seventy-one (47.5\%) were male and 189 (52.5\%) female.

The mean (SD) hemoglobin was $129 \mathrm{~g} / \mathrm{I}$ (1.26) with a range between $88 \mathrm{~g} / \mathrm{l}$ and $171 \mathrm{~g} / \mathrm{l}$. Ninety-one children (26.7\%) had anemia according to the WHO definition, with 19 (20.8\%) having a hemoglobin $<110 \mathrm{~g} / \mathrm{l}$. MCHC was available for 320 of the students. The MCHC of $11(12.1 \%)$ out of the 91 anemic students was below 30\%, and 20 (22\%) were microcytic and hypochromic. Seven (7.7\%) of the anemic students had iron deficiency anemia by $\mathrm{MCHC}$ and microcytic findings. The $\mathrm{MCHC}$ of a further 27 of the 91 anemic students was between $30 \%$ and $32 \%$, and they were suspected of having iron deficiency anemia. No macrocytosis or obvious hyper-segmented neutrophils were seen, and none of the samples showed hypochromia or numerous target cells. All hypochromic or microcytic samples were anemic. There were no cases of sickle-cell anemia. The highest prevalence of anemia (35.7\%) was observed in teenagers over 15 years and children under 8 (35.4\%) as shown in Figure 1. There was a statistically significant difference in the prevalence of anemia by age $(p<0.05)$ but not by sex or parents' education (data not shown).

One hundred and fifty-two (42\%) of the 360 stool samples had at least one parasite; $30.3 \%$ of the samples had only one parasite, $9.2 \%$ had 2 parasites, $2.5 \%$ had 3 , and only $0.3 \%$ had 4 or more. The prevalence of parasite ova by age is shown in Table 1. Older students seemed to have a higher prevalence, but this was not statistically significant ( $\chi^{2}$ for trend $p>0.05$ ), and Giardia lamblia was more prevalent in children under 8 and over 15 years of age than in chil-

Figure 1

Prevalence of anaemia by age.



error bar $=95 \%$ C.I.

Table 1

Prevalence of parasites by age group.

\begin{tabular}{|c|c|c|c|c|c|}
\hline \multirow{2}{*}{ Parasites } & \multicolumn{5}{|c|}{ Age group } \\
\hline & $\begin{array}{c}<8 \\
\mathrm{n}=108(\%)\end{array}$ & $\begin{array}{c}9-11 \\
n=124(\%)\end{array}$ & $\begin{array}{c}12-14 \\
n=85(\%)\end{array}$ & $\begin{array}{c}15< \\
n=43(\%)\end{array}$ & $\begin{array}{c}\text { Total } \\
\mathrm{n}=360(\%)\end{array}$ \\
\hline Hookworm & $5(4.6)$ & $8(6.5)$ & $6(7.1)$ & $4(9.3)$ & $23(6.4)$ \\
\hline Schistosoma mansoni & $3(2.8)$ & $1(0.8)$ & $1(1.2)$ & $1(2.3)$ & $6(1.7)$ \\
\hline Trichuris trichiura & $18(16.7)$ & $20(16.1)$ & $13(15.3)$ & $5(11.6)$ & $56(15.6)$ \\
\hline Ascaris lumbricoides & $28(25.9)$ & $32(25.8)$ & $26(30.6)$ & $17(39.5)$ & $103(28.7)$ \\
\hline Hymenolepsis nana & $3(2.8)$ & $4(3.2)$ & $3(3.5)$ & $1(2.3)$ & $11(3.0)$ \\
\hline Enterobius vermicularis & $1(0.9)$ & $1(0.8)$ & $3(3.5)$ & $0(0)$ & $5(1.4)$ \\
\hline Entamoeba histolytica & $26(24.1)$ & $14(11.3)$ & $16(18.8)$ & $6(14.0)$ & $62(17.2)$ \\
\hline Giardia lamblia & $20(18.5)$ & $9(7.3)$ & $4(4.7)$ & $5(11.6)$ & $38(10.6)$ \\
\hline At least one ova & $42(38.9)$ & $50(40.3)$ & $39(45.9)$ & $21(48.8)$ & \\
\hline
\end{tabular}


dren 9-11 and $12-14$ years old ( $p<0.01$ ). District 1 had the highest prevalence of Ascaris lumbricoides (39.4\%), followed by districts 5 and 4 ( $p=0.04)$. Similarly, Trichuris trichiura was found most commonly in district 1 (30.9\%), followed by districts 2 and 4 ( $p<0.01$ ). There was no significant difference between districts for the other parasites. There was no relationship between prevalence of parasite ova and parents' education $(p>0.05)$. Students who had no toilet or had a pit latrine had a higher prevalence of parasite ova than those who had a toilet, as shown in Figure 2 ( $p<0.01$ ). Prevalence of T. trichiura and A. lumbricoides was higher in students who had no toilet or a pit latrine $(p<0.01)$. However, prevalence of other ova and cysts was not related to the availability of a toilet. There was no significant difference between the main source of drinking water and parasites.

Table 2 describes the prevalence of parasites by the presence or absence of anemia. There was no association between the presence of parasites and anemia.

Prevalence of stunting, wasting, and mixed malnutrition (HAZ, WHZ, WAZ) was 5.4\%, 2.5\%, and $4.4 \%$ respectively. There were no significant differences in HAZ, HWZ, WAZ between those with and without anemia. On the other hand, HAZ (SD) for those with and without hookworm was -0.935 (1.032) and -0.212 (1.117), respectively $(p<0.05)$, and for those with and without Hymenolepsis nana was -1.106 (1.215) and -0.230 (1.112), respectively, as shown in Table 3 ( $p<0.05$ ). WAZ (SD) for students with and without hookworm was -0.937 (1.102) and -0.223 (1.124), respectively $(p<0.05)$. Simi-

Figure 2

Type of toilet and parasitic ova.

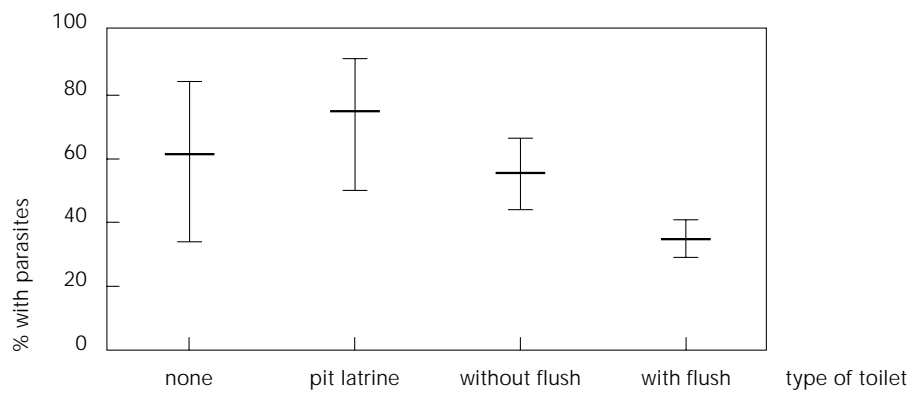

error bar $=95 \%$ C.I. larly, the difference between those with and without T. trichiura was statistically significant $(-0.610(0.853)$ and $-0.202(1.170)$ respectively) $(p<0.05)$.

\section{Discussion}

It is estimated that prevalence of anemia among children aged 6-12 years in tropical South America is 24\% (DeM aeyer, 1985). Our finding, a $26.7 \%$ prevalence rate for anemia in Aracaju's public primary school students, is in agreement with this figure. Iron deficiency anemia was present in $41.7 \%$ of the children with anemia, although this is difficult to assess when anemia is mild. Mean cell volume, serum ferritin, serum iron, and total iron binding capacity would help to confirm iron deficiency anemia, but this was not possible given the small blood volume taken.

Prevalence of anemia is higher in the youngest and oldest children ( $<8$ and $>15$ ). Preschool children and adolescents during growth spurts have the greatest physiological demands for iron and are at the highest risk of iron deficiency anemia (Viteri, 1997). Menstruating girls also have higher demands for iron; however, our teenagers had similar $\mathrm{Hb}$ levels in both sexes.

Prevalence of anemia in 1996 was $47.1 \%$ among 1,909 students under 8 years of age in the city's schools (Fapese, 1996). Prevalence of anemia in our children from this age group was $35.4 \%$ ( $p=0.02)$. This may be due to the season of the study and the characteristics of the schools selected, since the Fapese study included 4 schools from the rural area. Both studies showed that there were no statistically significant differences in the prevalence of anemia by sex or district.

The overall prevalence of parasite ova was $42 \%$, with A. lumbricoides, T. trichiura, and hookworm the being most frequently recorded. Worldwide, A. lumbricoides, T. trichiura, and hookworm are the most prevalent parasites, with hookworm being more common than T. trichiura (Warren et al., 1993). In the Fapese study, $88.3 \%$ of the students were positive for at least one parasite (Fapese, 1996). The highest prevalence was for A. lumbricoides (66.7\%) followed by T. trichiura (17.7\%) and hookworm (9.5\%).

We used concentration methods and random quality control checks to confirm that the prevalence of parasites in our children was reliable. Furthermore, water and sanitation services have improved in the last few years, al- 
Ratio of anemia among those with and without parasites.

\begin{tabular}{|c|c|c|c|c|}
\hline & \multicolumn{2}{|c|}{$\begin{array}{l}\text { Anemic students* }(n=91) \\
\text { positive }(\%) \quad \text { negative }\end{array}$} & \multicolumn{2}{|c|}{ Non-anemic students $(n=250$} \\
\hline Hookworm & $6(6.6)$ & 85 & $17(6.8)$ & 233 \\
\hline S. mansoni & $3(3.2)$ & 88 & $3(1.2)$ & 247 \\
\hline T. trichiura & $17(18.7)$ & 74 & $37(14.8)$ & 213 \\
\hline E. histolytica & $14(15.4)$ & 77 & $43(17.2)$ & 207 \\
\hline Hookworm + T. trichiura & $4(4.4)$ & 87 & $8(3.2)$ & 242 \\
\hline Hookworm + E. histolytica & $1(1.1)$ & 90 & $2(0.8)$ & 248 \\
\hline T. trichiura + E. histolytica & $2(2.2)$ & 89 & $3(1.2)$ & 247 \\
\hline
\end{tabular}

$p>0.05$

* According to WHO definition, see methods.

Table 3

Z scores of height-for-age, weight-for-height, and weight-for-age by anemia and parasites.

\begin{tabular}{|c|c|c|c|c|c|c|}
\hline & \multicolumn{2}{|c|}{ Height for Age } & \multicolumn{2}{|c|}{ Weight for Height } & \multicolumn{2}{|c|}{ Weight for Age } \\
\hline & Mean (SD) Z score & $\mathrm{n}<-2 \mathrm{Z}$ scores $/ \mathrm{n}(\%) \bullet$ & Mean (SD) Z score & $\mathrm{n}<-2 \mathrm{Z}$ scores $/ \mathrm{n}(\%) \bullet$ & Mean (SD) Z score & $\mathrm{n}<-2 \mathrm{Z}$ scores $/ \mathrm{n}(\%) \cdot$ \\
\hline Anaemia & $-0.331(1.150)^{*}$ & $5 / 89(5.6)$ & $-0.290(1.067)$ & $1 / 52(1.9)$ & $-0.333(1.028)^{*}$ & $4 / 89(4.5)$ \\
\hline No anaemia & $-0.232(1.117)^{*}$ & $14 / 262(5.3)$ & $-0.042(1.390)$ & $8 / 129(6.2)$ & $-0.245(1.169)^{*}$ & $12 / 262(4.6)$ \\
\hline \multicolumn{7}{|l|}{ Hookworm } \\
\hline positive & $-0.935(1.032)^{*}$ & 4 / 22 (18.2) & $-0.559(1.418)$ & $1 / 10(10.0)$ & $-0.937(1.102)^{*}$ & $6 / 22(27.3)$ \\
\hline negative & $-0.212(1.117)^{* \dagger}$ & $15 / 329(4.6)$ & $-0.087(1.300)$ & $8 / 171(4.7)$ & $-0.223(1.124)^{*}$ & $10 / 329(3.0)$ \\
\hline \multicolumn{7}{|l|}{ S. mansoni } \\
\hline positive & $0.153(0.793)$ & $0 / 6(0)$ & $-1.287(0.662)$ & $0 / 3(0)$ & $-0.682(0.713)$ & $0 / 6(0)$ \\
\hline negative & $-0.265(1.129)^{*}$ & $19 / 345(5.5)$ & $-0.093(1.307)$ & $9 / 178(5.1)$ & $-0.260(1.139)^{*}$ & $16 / 345(4.6)$ \\
\hline \multicolumn{7}{|l|}{ T. trichiuria } \\
\hline positive & $-0.400(1.013)^{*}$ & $4 / 56(7.1)$ & $-0.403(0.997)$ & $2 / 28(7.1)$ & $-0.610(0.853)^{*}$ & $5 / 56(8.9)$ \\
\hline negative & $-0.230(1.144)^{*}$ & $15 / 295(5.1)$ & $-0.060(1.352)$ & $7 / 153(4.6)$ & $-0.202(1.170)^{*}$ & $11 / 295$ (3.7) \\
\hline \multicolumn{7}{|c|}{ A. lumbricoides } \\
\hline positive & $-0.260(1.100)^{*}$ & $7 / 100(7.0)$ & $-0.292(1.259)$ & $3 / 46(6.5)$ & $-0.401(1.049)^{*}$ & $6 / 100(6.0)$ \\
\hline negative & $-0.256(1.136)^{*}$ & $12 / 251(4.8)$ & $-0.052(1.322)$ & $6 / 135(4.4)$ & $-0.214(1.164)^{*}$ & $10 / 251(4.0)$ \\
\hline \multicolumn{7}{|l|}{ H. nana } \\
\hline positive & $-1.106(1.215)^{*}$ & $3 / 11$ (27.3) & $0.185(1.849)$ & $1 / 6(16.7)$ & $-0.675(1.465)$ & $2 / 11(18.2)$ \\
\hline negative & $-0.230(1.112)^{* \dagger}$ & $16 / 340(4.7)$ & $-0.123(1.291)$ & $8 / 175(4.6)$ & $-0.254(1.122)^{*}$ & $14 / 340(4.1)$ \\
\hline \multicolumn{7}{|c|}{ E. vermicularis } \\
\hline positive & $-0.810(0.210)^{*}$ & $0 / 5(0)$ & $0.635(0.813)$ & $0 / 2(0)$ & $-0.322(0.617)$ & $0 / 5(0)$ \\
\hline negative & $-0.249(1.130)^{*}$ & $19 / 346(5.5)$ & $-0.121(1.311)$ & $9 / 179(5.0)$ & $-0.267(1.140)^{*}$ & $16 / 346(4.6)$ \\
\hline \multicolumn{7}{|l|}{ E. histolytica } \\
\hline positive & $-0.242(1.128)$ & 1 / 61 (1.6) & $-0.376(1.134)$ & $3 / 34(8.8)$ & $-0.374(1.004)^{*}$ & $3 / 61$ (4.9) \\
\hline negative & $-0.261(1.125)^{*}$ & $18 / 290(6.2)$ & $-0.052(1.340)$ & $6 / 147(4.1)$ & $-0.245(1.160)^{*}$ & $13 / 290(4.5)$ \\
\hline \multicolumn{7}{|l|}{ G. lamblia } \\
\hline positive & $-0.514(1.139)^{*}$ & $2 / 38(5.3)$ & $0.090(1.591)$ & $1 / 25(4.0)$ & $-0.243(1.365)$ & $2 / 38(5.3)$ \\
\hline negative & $-0.226(1.120)^{*}$ & 17 / $313(5.4)$ & $-0.146(1.259)$ & $8 / 156(5.1)$ & $-0.270(1.105)^{*}$ & 14 / $313(4.5)$ \\
\hline
\end{tabular}

$* p<0.05$ when compared to the NCHS standard.

$+p<0.05$ when children with and without the parasites are compared.

- number of children with a $Z$ score below -2 / number of children with the parasites. 
though this is unlikely to explain the lower prevalence in our study. The higher prevalence in 1996 was likely due to the highest prevalence of A. lumbricoides in the 4 schools from rural areas and the age distribution of the students, since prevalence of parasites is often age-related. Both studies showed a hookworm prevalence below $10 \%$ and lower than that of $\mathrm{T}$. trichiura. A study in 1991 and 1992 showed that prevalence rates for A. Iumbricoides, T. trichiura, Entamoeba histolytica, and G. Iamblia in children of low socioeconomic class (30\%, $36.7 \%, 40 \%$, and $63.3 \%$, respectively) were higher than those of wealthy children (3.3\%, $13.3 \%, 3.3 \%$, and 50\%, respectively) (Pereira de Aguiar et al., 1997).

There were only 6 cases of Schistosoma mansoni (1.7\%). This is in agreement with Pereira de Aguiar et al. (1997), who showed a prevalence of $1.8 \%$ in the region. It is not common for schoolchildren in Aracaju to play in the river or ponds, and urban dwellers have little exposure to infection.

Children usually become infected with hookworm, T. trichiura, and A. Iumbricoides from 6-12 months to 3 years of age (Kightlinger et al., 1995), and hookworm and A. lumbricoides infections increase with age, reaching a plateau in late adolescence and 4 to 10 years of age, respectively (Anderson, 1986; Stoltzfus et al., 1997a). The prevalence of a parasitic infection in our students increased with age.

The majority of students reported having a flush toilet (69.4\%) and access to tap water (88.1\%) at home. The availability of toilets varies among the city's neighborhoods. Students who had no toilet or only a pit latrine were more likely to be infected with parasites. Children from district 1 had both less access to toilets and the highest parasite prevalence.

We could not demonstrate an association between protozoan cysts and the type of drinking water, similar to Pereira de Aguiar et al. (1997), who reported that there was no association between $\mathrm{G}$. lamblia and drinking water.

The illiteracy rate $(7.2 \%$ of the fathers and $7.8 \%$ of the mothers) was lower than the reported illiteracy rate in the Northeast as a whole (30.5\%) (IBGE, 1997). However, the majority of the parents had not completed primary school. It was expected that there would be a relationship between the parents' education and anemia or parasitic infection, but we were unable to confirm this.

Hookworm is an important cause of anemia worldwide. Roche \& Layrisse (1966) and Pritchard et al. (1991) reported a significant negative correlation between plasma ferritin levels and hookworm load. Whether or not a person with hookworm infection develops anemia depends on the worm species and load, duration of infection, body iron stores, dietary intake and absorption, and physiological iron requirements. A low hookworm load can cause anemia in people whose intake of iron is low and whose iron stores are already depleted (Pawlowski et al., 1991). On the other hand, Michaelsen (1985) reported that hookworm did not cause severe anemia in infected children in Botswana, even in children with high worm loads, but most infections were light and a high iron intake was available. There was no association between anemia and hookworm, S. mansoni, or T. trichiura infections in our study, and all positive cases of hookworm had less than 1,300 hookworm epg of feces, which may not cause sufficient blood loss to cause anemia.

Robertson et al. (1992), reported that children with concomitant T. trichiura and hookworm infections have lower blood hemoglobin levels than children with neither or only one of these parasites. E. histolytica has been known to aggravate trichuriasis symptoms and to cause dysenteric syndrome (Gilman et al., 1976). We were unable to demonstrate any additive effect of concomitant infections between hookworm, T. trichiura, or E. histolytica.

The mean HAZ and WAZ score for Aracaju students was lower than those of the NCHS reference. In 1996, 11\% and 5.9\% of the children had a HAZ and WAZ < -2SD, respectively (Fapese, 1996).

Anemia can be a cause of growth retardation (Angeles et al., 1993; Stoltzfus et al., 1997b). However, there was no association between children with poor nutritional status and anemia. Most study populations have had lower hemoglobin levels than ours. For example, Stoltzfus et al. (1997b) showed that $62.3 \%$ of the children in Pemba Island, Tanzania, had less than $110 \mathrm{~g} / \mathrm{I}$ and in Jakarta, Indonesia, only children with $\mathrm{Hb}$ levels between 80 and $110 \mathrm{~g} / \mathrm{I}$ were selected (Angeles, 1993).

A statistically significant difference was shown in HAZ and WAZ between those with and without hookworm infection, and in WAZ between those with and without $\mathrm{T}$. trichiura. Hookworm, T. trichiura, and A. Iumbricoides antagonize the child's nutritional state through malabsorption, nutrient loss, altered metabolism, and diminished appetite (Cooper et al., 1992; Stephenson, 1994). Callender et al. (1994) reported that $\mathrm{T}$. trichiura caused more stunting than wasting. $H$. nana showed a statistically significant difference in $\mathrm{HAZ}$, although the num- 
ber of students with $\mathrm{H}$. nana was very low (7). Khalil et al.(1991) also reported that H. nana was associated with growth retardation in Egypt.

Sergipe is not an endemic malaria region, and there are other potential causes of anemia in our students: folate and vitamin B12 deficiencies, chronic infections, inflammatory diseases, and hemoglobinopathies like sickle-cell anemia and thalassemia. The result of thin blood films did not suggest these deficiencies, although macrocytosis may not be evident in mild anemia and may be masked by microcytosis of iron deficiency anemia. The cause of anemia in our students might still be mild iron deficiency anemia, which does not display microcytosis, or other nutritional deficiencies.

Three strategies can be adopted for the prevention of iron deficiency anemia, namely, iron supplementation, fortification of a staple food with iron, and the control of hookworm and other helminth infections. Studies in preschool children (Schultink et al., 1995; Palupi et al., 1997) have shown that intermittent iron supplementation is effective in improving hemoglobin levels, similar to that of daily iron sup-

\section{Acknowledgments}

We thank the office of the Ministry of Education in Sergipe for its support and the schoolchildren and teachers for their cooperation. Our special gratitude to Ms. C. Oliveira Rodrigues de Mendonça, Ms. J. Correa da Silva, Ms. F. Freire Feitosa, Ms. E Plech, and Ms. A. D. da Costa Pereira, students of the Federal University of Sergipe, for their enthusiastic assistance, especially in gathering data in the schools.

This study was submitted by R.T. as a thesis to obtain a Master of Tropical Medicine degree at the Liverpool School of Tropical Medicine, University of Liverpool. plementation which has been advocated by international health agencies.

The provision of iron to iron-deficient children improves growth (Chwang et al., 1988; Lawless et al., 1994). Several controlled trials have also demonstrated a positive impact of anti-helminth treatment on hemoglobin levels (Stephenson et al., 1985, 1989). The severity of anemia in Aracaju is mild and may be corrected by appropriate diet as long as the parents have sufficient knowledge about which foods are nutritional and how to prepare them properly. Parents and teachers may be able to collaborate to deliver health care and to control parasitic infections through chemotherapy (Savioli et al., 1992; Albonico et al., 1996). Intestinal parasite infections can be controlled with anti-helminth drugs in conjunction with education and improvement of sanitary conditions (Evans \& Stephenson, 1995) Most of the population in Aracaju have access to appropriate sanitary conditions and health facilities, and an eradication program through schools is an option that could be considered (Magnussen et al., 1997).

\section{References}

ALBONICO, M.; SHAMLAYE, N.; SHAMLAYE, C. \& SAVIOLI, L., 1996. Control of intestinal parasitic infections in Seychelles: a comprehensive and sustainable approach. Bulletin of the World Health Organization, 74:577-586.

ANDERSON, R. M., 1986. The population dynamics and epidemiology of intestinal nematode infections. Transactions of the Royal Society of Tropical Medicineand Hygiene, 80:686-696.

ANGELES, I. T.; SCHULTINK, W. J.; MATULESSI, P.; GROSS, R. \& SASTROAMIDJOJO, S., 1993. Decreased rate of stunting among anemic Indonesian pre-school children through iron supplementation. American Journal of Clinical Nutrition, 58:339-342. 
ASHFORD, R. W.; BARNISH, G. \& VIMEY, M. E.; 1992. A volumetric dilution method for counting eggs in preserved stools. Parasitology Today, 8:314318.

CALLENDER, J. E.; GRANTHAM-MCGREGOR, S.; WALKER, S. P. \& COOPER, E. S., 1994. Treatment effects in Trichuris dysentery syndrome. Acta Pediatrica, 83:1182-1187.

CHWANG, L. C.; SOEMANTRI, A. G. \& POLLITT, E., 1988. Iron supplementation and physical growth of rural Indonesian children. American Journal of Clinical Nutrition, 47:496-501.

COOPER, E.; WHYTE-ALLENG, C.; FINZI-SMITH, J. \& MacDONALD, T., 1992. Intestinal nematode infections in children: the pathophysiological price paid. Parasitology, 104:S91-S103.

DALLMAN, P. R., 1987. Iron deficiency and the immune response. American Journal of Clinical Nutrition, 46:324-329.

DEAN, A. G.; DEAN, J. A.; COULOMBIER, D.; BRENDEL, K. A.; SMITH, D. C.; BURTON, A. H.; DICKER, R. C.; SULLIVAN, K.; FAGAN, R. F. \& ARNER, T. G., 1995. Epilnfo Version 6: a Word-Processing, Database and Statistics Program for Public Health on IBM-Compatible Microcomputers. Atlanta: Centers for Disease Control and Prevention.

DeMAEYER, E. \& ADIELS-TEGMAN, M., 1985. The prevalence of anemia in the world. World Health Statistics Quarterly, 38:302-316.

DeMAEYER, E. M.; DALLMAN, P. \& GURNEY, J. M.; 1989. Preventing and controlling iron deficiency anemia through primary health care. Geneva: World Health Organization.

EVANS, A. C. \& STEPHENSON, L. S., 1995. Not by drugs alone: the fight against parasitic helminths. World Health Forum, 16:258-261.

FAPESE (Fundação de Apoio à Pesquisa e Extensão de Sergipe), 1996. Avaliação Clínica eMecanismos de Intervenção em Alunos Matriculados no Ensino Fundamental do Município de Aracaju, Sergipe. Sergipe: Fapese. (mimeo.)

FREIRE, W. B., 1997. Strategies of the Pan-American Health Organization/World Health Organization for the control of iron deficiency in Latin America. Nutrition Reviews, 55:183-188.

GILLESPIE, S.; KEVANY, J. \& MASON, J., 1991. Controlling Iron Deficiency. Geneva: Subcommittee of Nutrition (SCN), United Nations Administrative Committee on Coordination (ACC).

GILMAN, R. H.; DAVIS, C. \& FITZGERALD, F., 1976. Trichuris infection and amoebic dysentery in Orang Alsi children. A comparison of the two diseases. Transactions of the Royal Society of Tropical Medicine and Hygiene, 70:313-316.

IBGE (Instituto Brasileiro de Geografia e Estatística), 1997. Brazil in Figures, 5. Rio de Janeiro: Centro de Documentação e Disseminação de Informações, IBGE.

KHALIL, H. M.; EL SHIMI, S.; SARWAT, M. A.; FAWZY, A. F. \& EL SOROUGY, A. O., 1991. Recent study of Hymenolepsis nana infection in Egyptian children. Journal of the Egyptian Society of Parasitology, 21:293-300.

KIGHTLINGER, L. K.; SEED, J. R. \& KIGHTLINGER, M. B., 1995. The epidemiology of Ascaris lumbricoides, Trichuris trichiura, and hookworm in chil- dren in the Ranomafana rainforest. Madagascar Journal of Parasitology, 8:159-169.

LAWLESS, J. W.; LATHAM, M. C.; STEPHENSON, L. S.; KINOTI, S. N. \& PERTET, A. M., 1994. Iron supplementation improves appetite and growth in anemic Kenyan primary school children. Journal of Nutrition, 124:645-654.

LOZOFF, B.; JIMENEZ, E. \& WOLF, A. W., 1991. Longterm developmental outcome of infants with iron deficiency. New England Journal of Medicine, 325:687-694.

MAGNUSSEN, P.; MUCHIRI, E.; MUNGAI, P.; NDZOVU, M.; OUMA, J. \&TOSHA, S. A., 1997. School-based approach to the control of urinary schistosomiasis and intestinal helminth infections in children in Matuga, Kenya: impact of a two-year chemotherapy programme on prevalence and intensity of infections. Tropical Medicine and International Health, 2:825-831.

MICHAELSEN, K. F., 1985. Hookworm infection in Kweneng district, Botswana. A prevalence survey and a controlled treatment trial. Transactions of the Royal Society of Tropical Medicine and Hygiene, 79:848-851.

PALUPI, L.; SCHULTINK, W.; ACHADI, E. \& GROSS, R., 1997. Effective community intervention to improve haemoglobin status in pre-schoolers receiving once-weekly iron supplementation. American Journal of Clinical Nutrition, 65:1057-1061.

PAWLOWSKI, Z. S.; SCHAD, G. A. \& STOTT, G. J., 1991. Hookworm infection and anemia. Geneva: World Health Organization.

PEREIRA-DE-AGUIAR, C.; COSTA-DE-SANTANA, A. D. \& SÁ-CARDOSO, G., 1997. Prevalência e aspectos epidemiológicos da giardíase em creches no Município de Aracaju, Sergipe, Brazil. Revista Sergipana de Medicina, 1:43-49.

PRITCHARD, D. I.; QUINNEL, R. J. \& MOUSTAFA, M., 1991. Hookworm (Necator americanus) infection and storage iron depletion. Transactions of the Royal Society of Tropical Medicine and Hygiene, 85:235-238.

ROBERTSON, L. J.; CROMPTON, D. W.; SANJUR, D. \& NESHEIM, M. C., 1992. Hemoglobin concentrations and concomitant infections of hookworm and Trichuris trichiura in Panamanian primary school children. Transactions of the Royal Society of Tropical Medicine and Hygiene, 86:654-656.

ROCHE, H. \& LAYRISSE, M., 1966. The nature and causes of "hookworm anemia". American Journal of Tropical Medicineand Hygiene, 15:1031-1102.

SAVIOLI, L.; BUNDY, D. \&TOM KINS, A., 1992. Intestinal parasitic infections: a soluble public health problem. Transactions of the Royal Society of Tropical Medicineand Hygiene, 86:353-354.

SCHULTINK, W.; GROSS, R.; GLIWITZKI, M.; KARYADI, D. \& MATULESSI, P., 1995. Effect of daily vs twice weekly iron supplementation in Indonesian pre-school children with low iron status. American Journal of Clinical Nutrition, 61:111-115.

STEPHENSON, L. S.; LATHAM, M. C. \& KURZ, K. M., 1985. Relationships of Schistosoma hematobium, hookworm and malarial infections and metrifonate treatment to hemoglobin level in Kenyan school children. American Journal of Tropical Medicineand Hygiene, 34:519-528. 
STEPHENSON, L. S.; KINOTI, S. N. \& LATHAM, M. C., 1989. Single dose metrifonate or praziquantel treatment in Kenyan children. I. Effects on Schistosoma haematobium, hookworm, hemoglobin levels, splenomegaly, and hepatomegaly. American Journal of Tropical Medicine and Hygiene, 41:436-444.

STEPHENSON, L. S., 1994. Helminth parasites, a major factor in malnutrition. World Health Forum, 15:169-172.

STOLTZFUS, R. J., 1997. Rethinking anemia surveillance. Lancet, 349: 1764-1766.

STOLTZFUS, R. J.: DREYFUSS, M. L.; CHWAYA, H. M. \& ALBONICO, M., 1997a. Hookworm control as a strategy to prevent iron deficiency. Nutrition Reviews, 55:223-232.

STOLTZFUS, R. J.; ALBONICO, M.; TIELSCH, J. M .; CHWAYA, H. M. \& SAVIOLI, L., 1997b. Linear growth retardation in Zanzibari school children. Journal of Nutrition, 127:1099-1105.
VITERI, F. E., 1997. Iron supplementation for the control of iron deficiency in populations at risk. Nutrition Reviews, 55:195-209.

WARREN, K. S.; BUNDY, D. A. P.; ANDERSON, R. M.; DAVIS, A. R.; HENDERSON D. A.; JAMISON, D. T.; PRESCOTT, N. \& SENFT, A., 1993. Helminth infection. In: Disease Control Priorities in Developing Country (D. T. Jamison; W. H. Mosley; A. R. Measham \& J. L. Bobadilla, eds.), pp. 131-160, Oxford: Oxford University Press.

WATKINS, W. E. \& POLLITT, E., 1998. Nutrition, Health, and Child Development. Washington: Pan-American Health Organization/World Health Organization/World Bank/Tropical Metabolism Research Unit, University of the West Indies. 